\title{
A COMPREENSÃO DAS LEIS DE MENDEL POR ALUNOS DE BIOLOGIA NA EDUCAÇÃO BÁSICA E NA LICENCIATURA
}

The understanding of Mendel's laws by students of Biology during secondary school and undergraduation

\author{
Maria de Fátima Lima Fabrício ${ }^{1}$ \\ Zélia Maria Soares Jófili \\ Luiza Suely Martins Semen \\ Ana Maria dos Anjos Carneiro Leão
}

\section{RESUMO}

A dificuldade em compreender a transmissão dos caracteres hereditários, regidos pelas leis de Mendel é observada no ensino médio (EM) e superior (ES), possivelmente devido ao despreparo em conteúdos anteriores. Os objetivos deste estudo foram testar esta hipótese e verificar como essas dificuldades evoluíam no ES. Um questionário foi aplicado em turmas de EM e de ES (Licenciatura em Biologia, de três IES do Recife) para identificar as dificuldades dos alunos. Paralelamente, foram aplicados questionários e realizadas entrevistas semiestruturadas com os docentes de ambos os níveis, para identificar a percepção dos mesmos quanto às dificuldades de seus alunos e quais ações desenvolvem para ajudá-los. Quanto aos resultados, os problemas identificados no EM persistem entre os alunos do ES, a despeito do maior acesso a informações, o que se torna preocupante, pois os atuais alunos do ES serão os futuros professores do EM.

Palavras-chave: Leis de Mendel; aprendizagem conceitual; formação de professores.

\footnotetext{
${ }^{1}$ Secretaria de Educação PE/Escola Senador Novaes Filho UFRPE/PPGE-marlina@yahoo.com.br;UNICAP/UFRPE-jofili@uol.com.br; UFRPE/luisa@ufrpe.br; UFRPE/PPGEC-amanjos2001@yahoo.com.br;
} 


\section{ABSTRACT}

The difficulty of understanding the hereditary characters transmission, based on Mendel's laws is observed among Secondary School students (EM) as well as undergraduate students of Biology (ES), possibly due to the lack of knowledge of previous contents. The aim of this study has been to test this hypothesis and the way these difficulties appears in the ES. A questionnaire was elaborated to identify the difficulties among students of these two groups (EM and ES). Questionnaires and interviews also had been applied with secondary and university teachers to identify their perceptions about the difficulties of its students and the actions they develop to help them. In spite of the biggest access to information, the identified problems persist among the undergraduate students. The fact that they do not seem able to solve practical questions becomes preoccupying since they will teach in secondary school.

Keywords: Mendel's laws; conceptual learning; teacher education. 


\section{Introdução}

Desde sempre ouvimos "a escola precisa mudar", jargão tão antigo quanto a própria escola. No Brasil, essa discussão tem gerado ainda mais conflitos e desafios ao serem analisados os resultados do PISA (Programa Internacional de Avaliação de Alunos) que é organizado pela OCDE (Organização para a Cooperação e o Desenvolvimento Econômico) com o objetivo de avaliar e comparar as habilidades e conhecimentos de jovens de 15 anos. Apesar de não ser um dos 28 países membros da OCDE, o Brasil iniciou sua participação no programa em 2000. Os países avaliados são, em sua maioria, nações desenvolvidas. Outros três países em desenvolvimento (México, Rússia e Letônia) também participaram do exame. De acordo com a nota média dos alunos dos países, eles foram colocados em cinco diferentes níveis de aprendizado. O Brasil teve a pior média entre os 32 avaliados. Em 2001, esse resultado se agravou, pois outros dez países em desenvolvimento foram incluídos nesse teste, e o Brasil foi classificado em penúltimo $\left(41^{\circ}\right)$ lugar. Paralelamente, na pesquisa Literacy Skills for the World of Tomorrow (Alfabetização para o Mundo de Amanhã), divulgada em 2003 pela Organização das Nações Unidas para a Educação, Ciências e Cultura (UNESCO), os estudantes brasileiros obtiveram o penúltimo lugar, estando à frente apenas do Peru (DREYER, 2003). Assim, justificam-se os esforços em modificar a situação atual, que nos coloca nos últimos lugares do ranking de desempenho escolar (RISCHBIETER, 2003).

Os Parâmetros Curriculares Nacionais (PCN) (BRASIL, 1998) foram criados para ajudar a escola a se modernizar e a se adequar à tarefa de formação do cidadão e demonstram claramente a necessidade de mudança da escola quando afirmam:

Vivemos numa era marcada pela competição e pela excelência, em que progressos científicos e avanços tecnológicos definem exigências novas para os jovens que ingressarão no mundo do trabalho (p. 5).

Considerando-se esse contexto, uma revisão do currículo revela-se necessária, de forma a enfatizar a qualidade do processo ensino-aprendizagem, com a finalidade de tornar o aluno um cidadão, crítico, ativo e transformador da sociedade na qual está inserido. Esse currículo deve ter vínculos com os diversos contextos de vida dos alunos e ser baseado no domínio de competências básicas, e não mais no acúmulo de informações (BRASIL, 1999). Faz-se necessário, então, preparar 
professores profissionais dotados de uma base sólida de conhecimento e de criatividade para encontrar soluções e assumir compromissos com 0 desenvolvimento educacional, realizando mudanças que levem à melhoria da qualidade de vida de nossa população (PERRENOUD, 2001). Entretanto, constatar que há necessidade de mudanças não é o bastante; é imprescindível buscar formas realistas e exeqüíveis para o aperfeiçoamento do ensino nas escolas brasileiras. Segundo Schnetzler (2000), um dos maiores problemas na formação de professores de ciências é, sem dúvida, a desarticulação entre os conteúdos específicos e pedagógicos. Além disso, podem ser citadas outras dificuldades: o excesso de conteúdos ministrados em grande velocidade; a utilização acrítica dos livros didáticos e a ênfase num ensino meramente mnemônico. Tavares (2004, p.15) pondera:

Transmitir os conteúdos sem relacioná-los e integrá-los a problemáticas atuais, dificulta a compreensão do futuro professor e não o prepara para trabalhar essa integração na sua prática docente.

\section{O ensino da genética}

O desenvolvimento da Genética e da Biologia Molecular, das tecnologias de manipulação do DNA e de clonagem traz a tona aspectos éticos envolvidos na produção e aplicação do conhecimento científico e tecnológico chamando à reflexão sobre as relações entre a ciência, a tecnologia e a sociedade (BRASIL, 1999, p. 219).

Segundo Moreira e Silva (2001) e Canal e Bastos (2001), um dos problemas mais freqüentes no ensino da Biologia no EM, é o conteúdo de Genética, que exige do aluno conhecimentos prévios em diversas áreas, como: Biologia Molecular (estrutura das moléculas que organizam a estrutura e funcionamento da célula), Citologia (a qual deveria ser compreendida como Biologia Celular, compreendendo-se as diferentes etapas da vida de uma célula, ou seja, o ciclo celular e como os processos de Divisão Celular estão inseridos nesse contexto), Citogenética e fundamentos de raciocínio matemático (Frações, Probabilidades, Regra de Três). Para relacionar de forma adequada esses conhecimentos prévios aos novos conteúdos que estão sendo abordados, também é requerido raciocínio lógico, o que possibilitará ao aluno perceber relações existentes entre a transmissão das 
características hereditárias e o processo de divisão celular (meiose), responsável pela formação dos gametas (gametogênese), assim como o número de cromossomos presentes nas formas haplóide e diplóide das células, o que vai interferir na fecundação para gerar indivíduos idênticos aos preexistentes (COSTA, 2000).

A Biologia é uma área em constante mudança e com um caráter interdisciplinar elevado. Entretanto, cabe lembrar que sua origem vem da busca de pesquisadores por respostas às perguntas, que não lhes são exclusivas, visto que desde sempre, e em vários campos do conhecimento, essas questões vigoram: "De onde viemos? Como características encontradas em um ancestral distante podem aparecer em um descendente? Em que percentual essas características são transmitidas? Por que certas características aparecem mais que outras?". Em resposta a essas questões, várias teorias foram propostas, muitas em desuso, enquanto outras permanecem valiosas para a compreensão dos mecanismos da hereditariedade. Segundo Griffiths, Miller \& Suzuki (2002), para qualquer estudo sério da vida vegetal, animal ou microbiana, é essencial a compreensão da Genética, pois ela, como nenhuma outra disciplina, é fundamental para a compreensão de vários aspectos das questões biológicas.

A Genética, uma das ciências que mais evoluíram em nossos dias, é considerada fundamental para o desenvolvimento da biotecnologia, e ocupa lugar de destaque nas pesquisas biológicas atuais, contribuindo para a melhoria do padrão de vida do homem moderno, impulsionando setores como agricultura, medicina, ecologia, pecuária e farmacogenômica (XAVIER et al., 2002). Essa última foi viabilizada pelo surgimento das técnicas do DNA recombinante, que tornou possível fabricar medicamentos inoculando genes em microorganismos, induzindo-os à produção de substâncias desejáveis para uso terapêutico. Segundo Xavier et al. (2002), a partir do desenvolvimento e conclusão do Projeto Genoma Humano, foi possível à farmacologia desenvolver novas drogas baseadas nas reações e efeitos no organismo do paciente, baseando-se em seqüências genéticas variáveis (no polimorfismo em um único nucleotídeo, onde apenas uma base é modificada, quando comparada à mesma seqüência de DNA em indivíduos diferentes).

Os impactos das mudanças tecnológicas sobre nossas vidas são evidentes e causam interesse em nossos alunos, o que oferece ao professor uma excelente oportunidade de usufruir dessa curiosidade, para motivar o processo ensino- 
aprendizagem da Genética. A Genética, assim como a Biologia, encontra-se presente no nosso cotidiano, seja quando vamos à mesa e ingerimos produtos oriundos de organismos geneticamente modificados (OGM), ou ainda quando falam ou ouvem sobre bebês de proveta, teste de paternidade, projeto genoma, terapia gênica, transgênicos, ovelha Dolly, células-tronco e outros tantos assuntos. Assim, a contextualização frente ao cotidiano vem a ser um excelente instrumento para favorecer a construção de conhecimento (MERCADANTE \& FAVARETTO, 1999).

Os PCN e a genética

Conhecer a estrutura molecular da vida, os mecanismos de perpetuação, diferenciação das espécies e diversificação intraespecífica, a importância da biodiversidade para a vida no planeta, são alguns elementos essenciais para um posicionamento criterioso relativo ao conjunto das construções e intervenções humanas no mundo contemporâneo (BRASIL, 1999, p. 220-a).

Os PCN apontam para o desenvolvimento de competências que se iniciam na escola fundamental, porém não se restringindo a ela. Torna-se necessário, portanto, selecionar conteúdos e escolher metodologias coerentes com as intenções educativas almejadas. Entre essas se destaca compreender a natureza como uma rede de relações, um todo dinâmico e, nesse todo, o ser humano como parte integrante, atuante e dependente (BRASIL, 1999).

Os PCN incentivam a construção do conhecimento da estrutura molecular da vida, os mecanismos de perpetuação e diferenciação das espécies, além da diversificação intraespecífica e a importância da biodiversidade para a vida no planeta, como alguns dos elementos essenciais para um posicionamento criterioso relativo ao conjunto das construções e intervenções humanas no mundo contemporâneo. Tudo isso se obtém ao estudar a Genética e a Evolução. Daí a importância de desenvolver esse estudo de forma integrada aos acontecimentos de nosso cotidiano. A escolha sobre o quê e o como ensinar em Biologia, não deve ser estabelecida apenas como uma lista de tópicos, mas como uma forma de promover os objetivos estabelecidos pela Resolução CEB $n \cong 3$, CNE/98 (Conselho Nacional de Educação) para a área de Ciências da Natureza, Matemática e suas Tecnologias. Dentro da área de Biologia existem objetivos que podem ser relacionados à construção de uma visão de mundo, além de outros práticos e instrumentais para a 
ação e, ainda, aqueles que permitem a formação de conceitos, a avaliação e a tomada de posição cidadã.

Os PCNEM (PCN para o Ensino Médio) dizem que o ensino dos conteúdos de Genética deve apoiar-se no desenvolvimento de posturas e valores que corroborem com o desenvolvimento de relações entre os seres humanos entre si e com o meio, além de mediar relações entre o ser humano e o conhecimento, contribuindo assim para uma educação formadora de cidadãos. O trabalho desses conteúdos deve possibilitar reflexões e posicionamentos criteriosos, relativos ao conjunto das construções e intervenções humanas no mundo contemporâneo. (BRASIL, 1999).

Assim, torna-se fundamental descrever o material genético quanto a sua estrutura molecular e composição química, explicar os processos envolvidos na síntese protéica e sua relação com as características dos seres vivos e os processos de reprodução celular. A articulação entre esses conceitos deve ser trabalhada cuidadosamente, pois é conceito fundamental para a compreensão de como a hereditariedade acontece. Especificamente, tratar das leis de Mendel e algumas de suas derivações, como os alelos múltiplos, herança quantitativa e herança ligada ao sexo, bem como a recombinação gênica requer um trabalho conjunto com noções de probabilidade, análise combinatória e bioquímica para dar significado às leis da hereditariedade. A posse desses conhecimentos possibilita ao aluno compreender as tecnologias de clonagem, engenharia genética e outras ligadas à manipulação do DNA (BRASIL, 1999).

\section{Objetivo Geral}

- Identificar as dificuldades encontradas pelos alunos do Ensino Médio (EM) e da Licenciatura em Biologia (ES), relacionadas à aprendizagem da $1^{\underline{a}}$ e $2^{\underline{a}}$ leis de Mendel.

\section{Objetivos Específicos}

- Identificar as relações que os alunos de Biologia (EM e ES) estabelecem entre Biologia Celular e Molecular (ácidos nucléicos e síntese protéica) e Divisão Celular (meiose) com a transmissão dos caracteres hereditários, ao trabalharem as Leis de Mendel.

- Identificar as concepções prévias dos alunos do Ensino Médio e licenciandos de Biologia, acerca da transmissão das características hereditárias. 
Metodologia

Para identificar os obstáculos à compreensão das leis de Mendel por alunos de biologia da Educação Básica e da Licenciatura, trabalhamos com alunos do EM ( $\mathrm{n}=$ 136), de duas instituições públicas estaduais (Escola Senador Novaes Filho e Escola Prof. Olinto Victor) e com licenciandos (67) de cursos de Licenciatura em Biologia de três IES da Região Metropolitana do Recife (Fundação de Ensino Superior de Olinda - FUNESO, Universidade Federal Rural de Pernambuco - UFRPE e Universidade Católica de Pernambuco - UNICAP).

Como instrumento de pesquisa, utilizamos um questionário, com a finalidade de buscar subsídios para ajudar a responder às indagações iniciais: Quais são as dificuldades para a compreensão das leis de Mendel? Por que esse tópico é tão difícil de ser trabalhado pelo professor e de ser compreendido pelos alunos? A aplicação do mesmo questionário aos alunos do ES e do EM deve-se ao interesse em investigar se os obstáculos epistemológicos identificados no EM persistem no ES, pois os licenciandos estarão ingressando no mercado de trabalho, o qual certamente será uma sala de aula, onde irão trabalhar esse conteúdo.

\section{Resultados}

As respostas obtidas foram categorizadas e expressas em percentuais. Em seguida, foram tecidos alguns comentários e apresentadas considerações comparativas entre os resultados do ES e do EM.

Questão 1: Você acha difícil entender a transmissão dos caracteres hereditários? Por que? Resposta esperada: Nesse caso, a resposta poderia ser afirmativa ou negativa, dependendo apenas da afinidade com a Genética, porém a justificativa deveria refletir sua resposta e estar condizente com as respostas das demais questões propostas.

Dos cento e trinta e seis (136) alunos do EM que responderam a questão 1, vinte e nove (29) a acharam fácil (tabela 1); 76 a acharam difícil e trinta e um (31) a consideraram mais ou menos difícil (tabela 2). Dos sessenta e sete (67) licenciandos que responderam à questão, trinta e três (33) a acharam fácil (tabela 1), vinte e 
quatro (24) a consideraram difícil (tabela 2); quatro (4) a consideram mais ou menos difícil e seis (6) não responderam.

Tabela 1 - Alunos do EM e ES que acharam fácil o entendimento da transmissão dos caracteres hereditários

\begin{tabular}{l|r|r|r|r}
\multicolumn{1}{c}{ Respostas à Questão 1 } & № & $\%$ & \multicolumn{2}{c}{ ES } \\
& resp & & resp & \\
& 11 & 37,9 & 19 & 57,6 \\
$\begin{array}{l}\text { É fácil. Demonstraram } \\
\text { entender }\end{array}$ & & & & \\
\hline $\begin{array}{l}\text { É fácil. Não demonstraram } \\
\text { entender. }\end{array}$ & 18 & 62,1 & 14 & 42,4 \\
\hline Total & 29 & 100, & 33 & 100, \\
& & 0 & & 0 \\
\hline
\end{tabular}

Para vinte e nove (29) desses alunos, é fácil entender, porque basta prestar atenção e usar a lógica, porém, dezoito (18) não demonstram entender esses mecanismos nas questões seguintes. Dentre os que consideraram a questão fácil, apenas onze (11) do EM e dezenove (19) do ES, respectivamente, 37,9\% e 57,6\% confirmaram sua compreensão ao responder corretamente às questões posteriores.

Tabela 2 - Alunos do EM e ES que acharam difícil o entendimento da transmissão dos caracteres hereditários

\begin{tabular}{|c|c|c|c|c|}
\hline \multirow[b]{2}{*}{$\begin{array}{c}\text { Respostas questão } \\
1\end{array}$} & \multicolumn{2}{|c|}{ EM } & \multicolumn{2}{|c|}{ ES } \\
\hline & $\begin{array}{c}\text { № } \\
\text { resp }\end{array}$ & $\%$ & $\begin{array}{l}\text { № } \\
\text { resp }\end{array}$ & $\%$ \\
\hline Difícil. & 76 & 55,9 & 24 & 35,8 \\
\hline $\begin{array}{l}\text { Mais ou menos } \\
\text { difícil }\end{array}$ & 31 & 22,8 & 6 & 9,0 \\
\hline Não responderam & - & - & 4 & 6,0 \\
\hline Total & 107 & $\begin{array}{r}99,9 \\
9\end{array}$ & 34 & $\begin{array}{r}100 \\
0\end{array}$ \\
\hline
\end{tabular}


Entre os alunos do EM, setenta e seis (76) indivíduos (ou 55,9\%) consideraram difícil entender a transmissão dos caracteres hereditários. Os motivos alegados são quase sempre os mesmos (Ihes faltam assuntos anteriores).

Por outro lado, vinte e quatro (24), (ou 35,8\%) foram enfáticos ao afirmarem que o assunto é difícil de entender, porque requer conhecimentos em assuntos anteriores, dos quais eles não lembram. Seis (6 ou 9\%) responderam que consideram o assunto relativamente difícil, talvez com receio de revelar suas dificuldades no assunto, e outros quatro (4) correspondendo a 6\%, não responderam à questão, possivelmente pelos mesmos motivos dos anteriores. Analisando as respostas dos trinta e três licenciandos que responderam que acham fácil entender a transmissão dos caracteres hereditários, observa-se uma grande contradição, pois eles se confundiram nas respostas das questões seguintes, que avaliavam o conhecimento específico, o que demonstra serem os que mais precisam de ajuda. As respostas obtidas nesta questão demonstram que mesmo entre os licenciandos, futuros professores, as dificuldades de compreensão da transmissão dos caracteres hereditários ainda se encontram presentes. Suas justificativa para as dificuldades são, quase sempre, a necessidade de conhecimentos prévios que não dominam. Alguns justificam suas dificuldades alegando não ser a genética sua área de interesse, o que é preocupante uma vez que um licenciado em Biologia atuando no Ensino Médio não poderá se dar ao luxo de escolher uma área de interesse. 0 professor tem que trabalhar todo o conteúdo programático, inclusive a genética.

Comparando as respostas obtidas nos dois grupos, observamos que os perfis dos alunos de EM e ES são bastante semelhantes. Entre os que consideraram ser fácil a compreensão, $62,1 \%$ e $42,4 \%$ dos alunos do EM e ES, respectivamente, demonstraram que seu entendimento é falho, ao responderem as demais questões. Os motivos apresentados pelos dois grupos são praticamente os mesmos, com o agravante de alguns alunos afirmarem que "não viram os assuntos" que Ihes serviriam de base (subsunçores, na concepção de Ausubel) para a construção desse conhecimento. Ao compararmos os resultados, percebemos que a diferença entre eles é de apenas 19,7\%, o que é fator preocupante, pois estamos tratando igualmente alunos pertencentes a níveis distintos de escolaridade e que um dos grupos é de futuros formadores do EM.

As respostas das demais questões estão sumarizadas nos Gráficos $1 \mathrm{~A}$ (alunos do Ensino Médio) e 1 B (licenciandos em Biologia). 


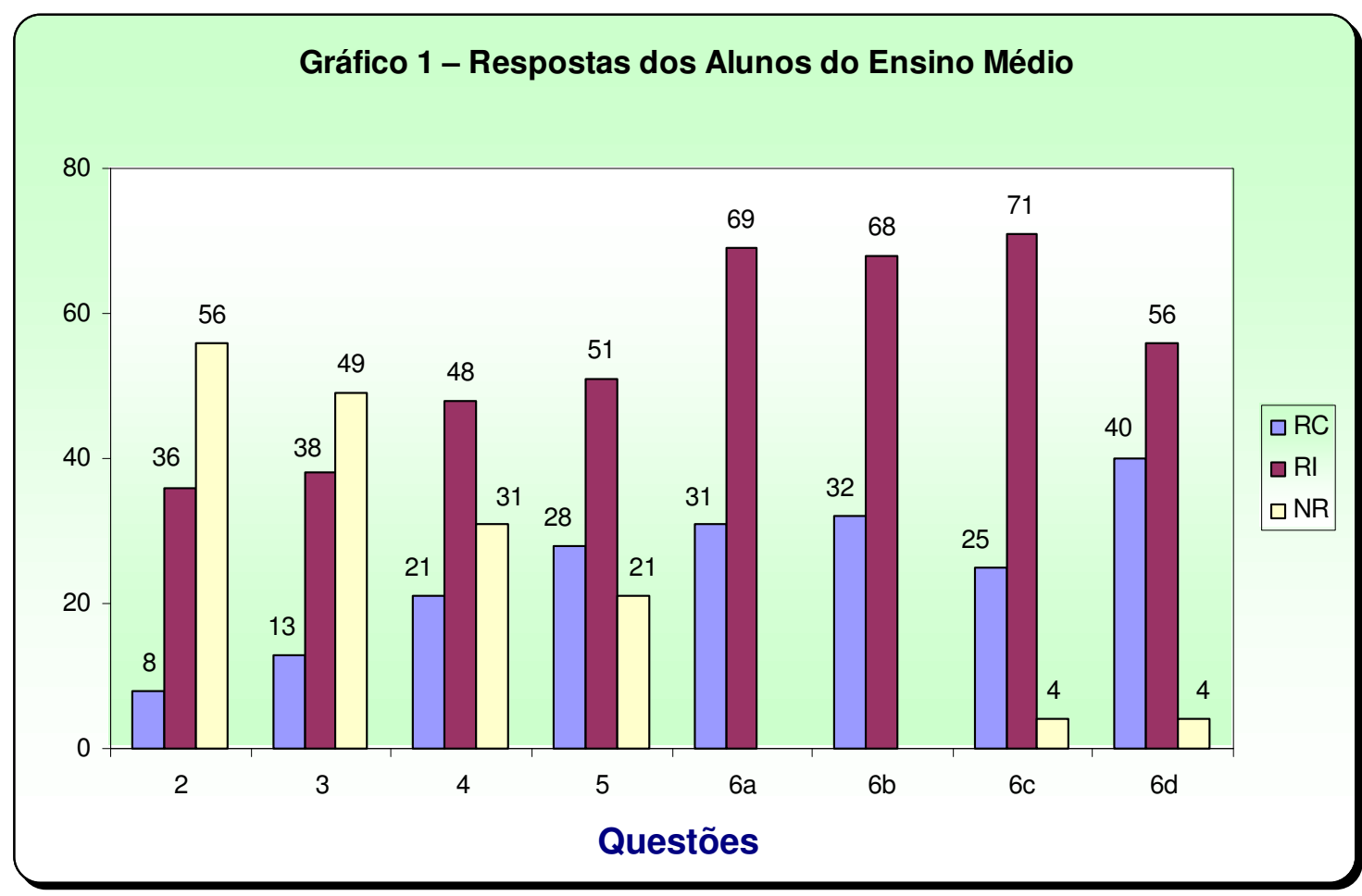

$\mathrm{RC}=$ Respostas corretas

$\mathrm{RI}=$ Respostas Incorretas

$\mathrm{NR}=$ Não Respondeu

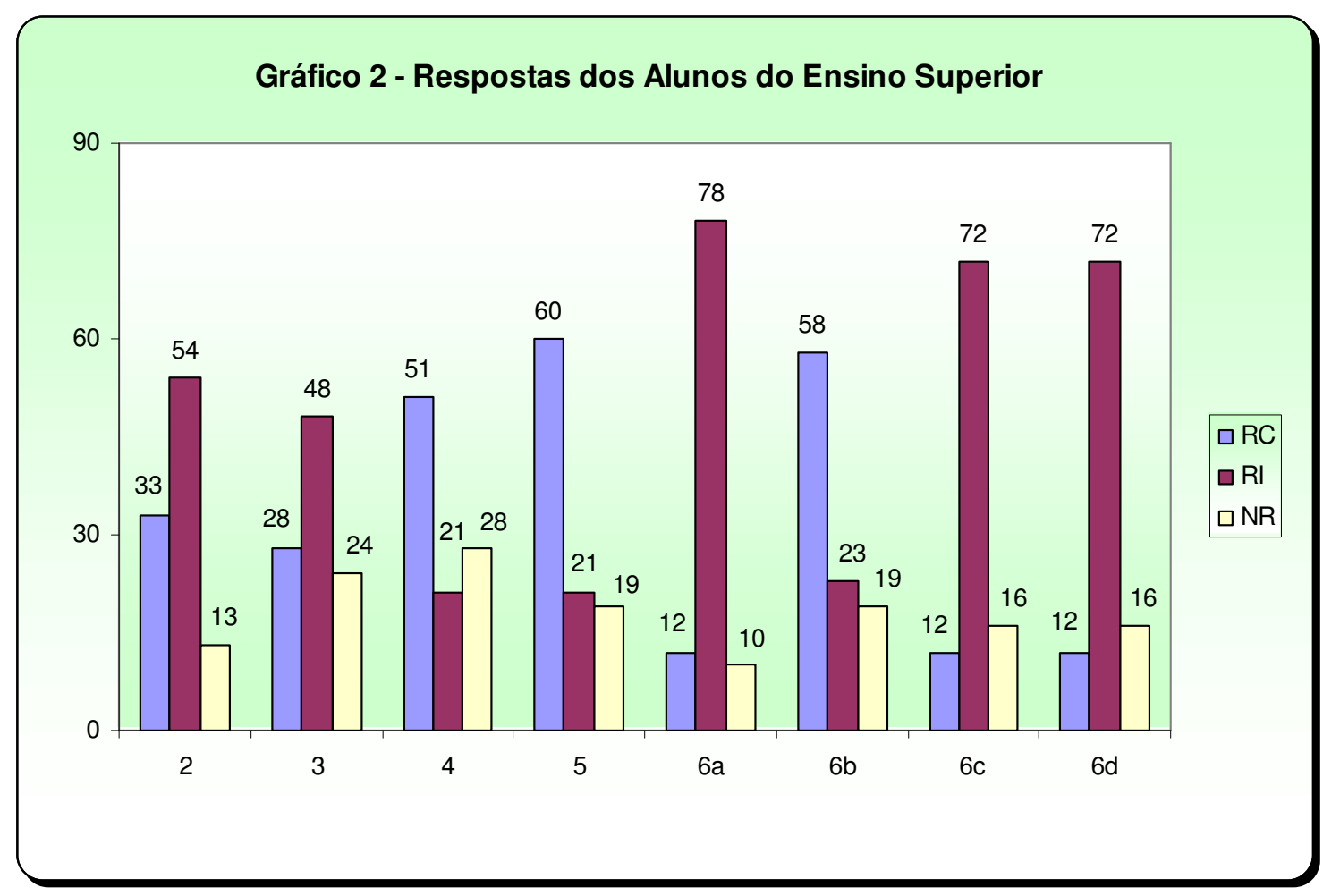

NR = Não Respondeu 
Questão 2: Na sua opinião, o que são genes? Explique em poucas palavras como você acha que se processa a transmissão das características de pais para filhos. Resposta esperada: Segundo Motta (2000, p. 17) "o gene corresponde a um trecho da molécula de DNA com informação genética. Uma vez que o DNA apresenta trechos sem informação codificável, nem todo trecho de DNA é um gene. Quanto às características transmitidas dos pais para os filhos, estas ocorrem através dos gametas, os quais possuem um genoma constituído pelos genes do genitor doador do gameta".

Entre os alunos do EM, apenas onze (11) deram respostas corretas ao definirem o que são genes, num percentual de acerto de apenas $8,1 \%$. Vale salientar que $13,2 \%$ dos alunos deram elementos e pistas de que saberiam responder a questão se soubessem articular as palavras. Um dos professores salientou que a maior dificuldade desses alunos é de colocar no papel aquilo que sabem, pois Ihes falta o domínio do português. Em contra partida setenta e seis (76) dos cento e trinta e seis (136) alunos num percentual de 55,9\% não responderam ao que solicitava a questão, e 22,8\% deram respostas sem sentido.

No ES observou-se um percentual de acerto de $32,8 \%$. Nove alunos deixaram sem resposta esse item, o que é grave, visto que o gene é o material de estudo da genética e, se esses futuros professores não são capazes, em sua maioria, de definir o que é um gene, como poderão trabalhar esse conceito? A segunda parte dessa questão solicitava uma breve explicação de como se processa a transmissão das características de pais para filhos, o que na realidade está diretamente relacionado com a ação dos genes presente nos gametas. Nessa segunda parte, o percentual de acerto no ES foi ainda menor (29,8\%). Porém, vale salientar que na primeira parte da questão, $13,2 \%$ dos alunos citaram elementos, mas não conseguiram formular uma resposta correta para a questão, provavelmente devido à deficiência que têm para redigir. No ES obtivemos um percentual de acerto na primeira parte da questão de $32,8 \%$, e na segunda parte da questão o percentual de acerto foi de $29,8 \%$. Nessa questão o percentual de acertos e erros entre os dois grupos apresentou um distanciamento maior. Mesmo assim, preocupante, uma vez que no ES apenas 30\% desses alunos foram capazes de responder corretamente a questão. 
Avaliados de forma comparativa, apenas $8,1 \%$ dos alunos do EM deram respostas corretas ao definirem o que são genes, e 13,2\% explicaram corretamente como as características são transmitidas de pais para filhos. Porém, vale salientar que na primeira parte da questão, $13,2 \%$ dos alunos citaram elementos, mas não conseguiram formular uma resposta correta para a questão, provavelmente devido à deficiência que têm para redigir. No ES obtivemos um percentual de acerto na primeira parte da questão na ordem de $32,8 \%$, e na segunda parte o percentual de acerto foi de $29,8 \%$.

Questão 3: Segundo o que você entende sobre a transmissão dos caracteres hereditários, como uma característica de minha tia-avó pode aparecer no meu neto? Resposta esperada: Essa questão ainda envolve o conhecimento dos genes, bem como a noção de dominância e recessividade. A característica é RECESSIVA.

Essa questão envolvia os conhecimentos sobre transmissão de características, formação de gametas, bem como noções de dominância e recessividade. Quando uma característica encontra-se em um membro da família e desaparece, vindo reaparecer em membros de gerações futuras indica que se trata de um gene recessivo. Na questão, uma característica encontrada na tia-avó, só volta a aparecer no neto, indica que o gene que a condiciona é recessivo e que não encontrou condições de homozigose anteriormente, que favorece a expressão de características recessivas. Comparando os resultados obtidos entre os dois grupos, $13,2 \%$ e $28,3 \%$ entre alunos do EM e ES, respectivamente, acertaram a questão, acarretando uma diferença de $15 \%$ a favor do grupo do ES. Observando o percentual de erros dos dois grupos, veremos que em termos percentuais os licenciandos erraram mais (47,8\%). Não é admissível que alunos de Biologia, de nível superior errem tanto numa questão simples, e que $23,9 \%$ nem se arriscaram a responder, deixando a questão em branco.

Questão 4: Algumas pessoas demonstram uma sudorese excessiva, mesmo em condições ambientais normais. Essa característica é determinada por um alelo dominante S. Como será o genótipo de uma pessoa normal? Resposta esperada: A única resposta correta seria apenas: ss.

Nessa questão, entre os alunos do EM obtivemos 21,3\% de acerto. Entre os demais, alguns aspectos puderam ser observados: $13,2 \%$ disseram que se tratava de uma característica recessiva, o que é verdadeiro, mas não atendia ao que 
solicitava a questão; 14,7\% afirmaram se tratar de um alelo recessivo, o que também é verdadeiro, mas não atende à questão. Assim, concluímos que trinta e oito alunos sabem do que estamos tratando, mas não deram a resposta esperada.

Entre os sessenta e sete (67) alunos do ES, foram encontradas nove respostas diferentes, onde só havia uma única resposta correta (ss). Apenas 34 alunos responderam corretamente $(50,7 \%)$, o restante, quase cinqüenta por cento, erraram ou deixaram sem resposta. Entre esses, três (3) colocaram como resposta o genótipo Ss, o que condiciona um indivíduo heterozigoto com sudorese excessiva; três (3) responderam SS, o que também condiciona sudorese excessiva, quatro (4) responderam apenas $S$, demonstrando que não saber a diferença entre genótipo, gene e alelo; um (1) disse genótipo dominante recessivo; um (1) outro disse apenas recessivo, sem fornecer o genótipo; um (1) outro respondeu $A A, A a$ e aa, demonstrando a memorização sem saber seu significado; e, finalmente, um (1) outro respondeu genótipo dominante; o que demonstra importante falha conceitual, pois o fenótipo expresso seria de sudorese excessiva, e dezenove (19) não responderam.

Essa questão foi elaborada envolvendo conhecimentos relativos a genótipo, fenótipo, genes e alelos, que são conceitos essenciais para a compreensão da transmissão de características hereditárias. Comparando-se os resultados obtidos entre os dois grupos os acertos no ES foram de 50,7\% e no EM foi de $21,32 \%$, perfazendo uma diferença $29,4 \%$, a favor do ES. Entretanto, se observarmos o percentual de respostas erradas ou em branco obteremos cerca de $50 \%$, um percentual elevado para um grupo de licenciandos.

Questão 5: Como se denomina o fenômeno que origina células haplóides a partir de células diplóides? Resposta esperada: Para essa questão só havia uma única resposta: MEIOSE.

Nessa questão trinta e oito (38) alunos do EM (equivalendo a 28\%) responderam corretamente; $33,8 \%$ se confundiram e deram como resposta a MITOSE, como sendo responsável pela produção de células haplóides a partir de células diplóides; 16,9\% dos alunos deram respostas sem sentido, como por exemplo, "produção das ervilhas de Mendel" e, finalmente, vinte e nove (29) alunos deixaram sem resposta a questão.

No ES obtivemos onze respostas diferentes onde havia apenas uma, Meiose. Quarenta (40) alunos deram a resposta esperada em um percentual de 59,7\%. Um licenciando citou a gametogênese que é o processo de formação dos gametas e que 
realmente se dá partindo-se de células diplóides originando os gametas, que são células haplóides. Vale ressaltar que entre os vinte e sete alunos restantes, 19,4\% não responderam à questão e 20,9\% deram respostas absurdas. Esse perfil sugere que os alunos receberam as informações necessárias, mas não as articularam adequadamente, permanecendo como informações soltas e sem sentido.

Questão 6: De acordo com as leis de Mendel, que tipos de gametas podem ser produzidos pelos indivíduos com os genótipos abaixo? a) Aa produzem que tipos de gametas? b) AaBb produzem que tipos de gametas? c) AB produzem que tipos de gametas? d) AA produzem que tipos de gametas? Respostas esperadas: Na subquestão $\mathrm{a}$, produzem gametas dos tipos $\mathbf{A} \mathbf{e} \mathbf{a}$; $\mathrm{Na}$ subquestão b, produzem gametas AB, Ab, aB e ab; Na subquestão c, produzem gametas dos tipos $\mathbf{A}$ e $\mathbf{B} ; \mathrm{Na}$ subquestão d, produzem apenas gametas do tipo $\mathbf{A}$.

A 6aquestão foi elaborada com a finalidade de verificar se os alunos sabem como se formam os gametas a partir dos genótipos e se relacionam os processos de divisão celular e de formação dos gametas, com as leis de Mendel. A subquestão 6a, perguntava os tipos de gametas formados por indivíduos com genótipo $\mathrm{Aa}$, os quais produzem apenas gametas dos tipos A e a. Entre os sessenta e sete (67) licenciandos que responderam a subquestão 6 a apenas 11,9\% deram a resposta correta; $10,4 \%$ deixaram essa questão sem resposta e os $77,6 \%$ restantes erraram a resposta. O resultado obtido demonstra que os obstáculos epistemológicos à compreensão das leis de Mendel detectados no EM ainda estão presentes no ES. Entre os cento e trinta e seis (136) alunos do EM, quarenta e dois acertaram a questão (30,9\%). A taxa de acerto na questão $6 \mathrm{a}$, no $\mathrm{EM}$, foi bastante significativa, quase o triplo do percentual de acerto no ES e, não encontro explicação para justificar tal desempenho. Os dois grupos de alunos apresentaram percentual de erros em torno de $70 \%$, o que é bastante elevado para o ensino médio e inadmissível no ensino superior.

A subquestão $6 \mathrm{~b}$ perguntava os tipos de gametas formados por indivíduos com genótipo $A a B b$, os quais produzem gametas dos tipos $A B, A b, a B$ e ab. Entre os alunos do EM, 31,6\% responderam corretamente a essa questão, enquanto $68,4 \%$ deram respostas erradas. O número de erros encontrado entre esses alunos foi muito elevado mesmo sendo do EM. No ES, 58,2\% responderam corretamente. Entretanto, 19,4\% deixaram essa questão sem resposta; e os $22,4 \%$ restantes erraram a resposta. $O$ percentual de acerto foi elevado em relação aos resultados 
anteriores, porém 41,8\% deles erraram ou não responderam à questão, sugerindo que os obstáculos epistemológicos à compreensão de conceitos relativos a 1ำ lei de Mendel da pureza dos caracteres detectados no EM ainda estão presentes no ES.

A subquestão $6 \mathrm{c}$ perguntava quais os tipos de gametas formados por indivíduos com genótipo $A B$, que produzem gametas dos tipos $A$ e $B$. No EM obtivemos trinta e quatro respostas corretas (25\%); 3,6\% não responderam, e 71,4\% desses alunos não foram capazes de encontrar os gametas de um indivíduo a partir de seu genótipo, percentual muito elevado mesmo para o EM. Entre os licenciandos, encontramos dez respostas distintas. O número de respostas incorretas entre esses alunos foi alarmante, visto que $71,6 \%$ dos licenciandos não conseguiram acertar a resposta e quando somados ao número de licenciandos que não responderam, obtemos um percentual elevadíssimo de $88,1 \%$ dos licenciandos sem base no conteúdo solicitado.

A subquestão 6d perguntava quais os tipos de gametas formados por indivíduos com genótipo AA, os quais produzem gametas apenas do tipo A.

No EM encontramos cinqüenta e quatro respostas corretas entre os cento e trinta e seis (136) alunos, num percentual de 39,7\%. O percentual de erros foi de $55,9 \%$ que somado ao percentual de questões não respondidas totaliza $60,3 \%$, 0 que é bastante elevado mesmo para o EM de escola pública. No ES encontramos apenas oito respostas corretas num percentual de apenas $12 \%$, o que é muito baixo. Entre os alunos que erraram temos um percentual de $71,6 \%$ e entre os que não responderam encontramos $16,4 \%$, somando-se esses percentuais teremos $88 \%$ de licenciandos com dificuldades na construção de seus conhecimentos.

\section{Conclusões}

Ao observar as respostas dos alunos do EM e do ES, foi verificado que os percentuais de acertos entre os mesmos são bastante próximos, o que faz pensar que as dificuldades desses alunos, independentemente do nível de escolaridade, são as mesmas, ou seja, segundo seus professores "os alunos não têm base", "chegam ao terceiro ano do ensino médio ou à universidade despreparados", e o que é pior, "não conseguem seguir o ritmo da universidade". Para piorar essa situação, decoram alguns conceitos para serem utilizados nos exames na faculdade ou na escola, e depois os mesmos são descartados, pois não encontram apoio, 
âncoras ou subsunçores que sirvam de ponte para se consolidarem em conhecimento verdadeiro. Diferente das respostas dos alunos do ensino médio, onde os erros eram quase sempre os mesmos, entre os licenciandos observamos que os erros eram diversificados, demonstrando que esses alunos obtiveram durante o curso superior um aumento no número das informações, porém as mesmas estão soltas e, esses licenciandos não conseguem relacionar as informações obtidas aos fatos relativos à transmissão dos caracteres hereditários, num contexto fora da sua sala de aula. Compreender o processo de transmissão dos caracteres hereditários, ou qualquer outro conceito requer muito mais que processos meramente mnemônicos. Implica construir modelos os quais são periodicamente visitados e revisitados para que sejam atualizados e, relacionados com os novos conhecimentos.

O papel do professor é interagir com seus alunos, procurando conhecer suas formas pessoais de aprender, para poder dar apoio aos mesmos na testagem de hipóteses, e assim ampliarem seus modelos mentais e desenvolverem suas estruturas cognitivas. Um dos professores do ensino superior diz que seus alunos apresentam alguma dificuldade em relacionar as leis de Mendel aos ciclos de vida, ou seja, não percebem o conteúdo na prática, ora é juntamente aí que se percebe que esses alunos não construíram esse conhecimento, apenas estão conseguindo passar na disciplina, usando talvez de artifícios que são peculiares aos alunos. Esse mesmo professor ainda completou dizendo: "[...] mas se não sabem, serão reprovados, para aprender". Será que reprovar é a solução? Irá fazer com que esses alunos construam esse conhecimento básico para a compreensão desse conteúdo? Repetir a mesma disciplina, com o mesmo professor e da mesma forma não ajuda, pois a deficiência está em disciplinas anteriores ou no próprio professor.

Seria ilusório pensar que os licenciandos chegam à sala de aula preparados para auxiliar seus alunos a construir seus conhecimentos, ou seja, ensinar, pois sabemos que a dura tarefa de ensinar se aprende no fazer diário, mas nada impede que esse recém-professor chegue a sua sala de aula sabendo interagir o conteúdo teórico específico com o pedagógico.

Com base nas respostas obtidas com a aplicação do teste descobriu-se a importância deste trabalho ao identificar as dificuldades encontradas pelos alunos do EM e do ES, relacionadas à compreensão dos processos de transmissão dos caracteres hereditários, que são responsáveis pelas dificuldades referentes à 
construção do conhecimento relativo às $1^{\text {a }}$ e $2^{\underline{a}}$ leis de Mendel. Acredita-se que esse trabalho é importante para todos os professores em exercício da docência, tanto no nível médio como, e em especial, nas licenciaturas, que estão formando novos professores sem lhes oferecer as possibilidades mínimas de instrumentalização para sua prática docente futura. Faz-se necessário encontrar uma maneira de minimizar os problemas por nós identificados.

Sugerimos que haja uma reformulação do conteúdo a ser trabalhado e uma conscientização dos professores quer no EM quer no ES. Neste sentido seria recomendável a divulgação de estudos como este nas salas de aula para que, cônscios dos resultados os professores replanejassem suas estratégias didáticas. É necessário que os professores de Biologia dominem os aspectos biológicos de sua disciplina, mas no caso dos professores das licenciaturas é fundamental que estejam conscientes de que o produto de seu trabalho irá para uma sala de aula, e que para isso, terão que garantir aos licenciandos uma formação diferenciada do biólogo que irá trabalhar numa bancada de um laboratório. O problema é que por muito tempo, para se ensinar na universidade não era - e em muitos casos ainda não é - necessário ter uma formação pedagógica. Para lecionar no ensino médio, embora seja exigida uma formação pedagógica, esta tem deixado a desejar seja porque é feita nas licenciaturas com professores de disciplinas específicas sem formação pedagógica e com professores de disciplinas pedagógicas sem conhecimentos na área especifica dos alunos. Além disso, muitas vezes essas disciplinas são ministradas em turma heterogêneas onde se agrupam alunos de várias licenciaturas.

Os PCNEM de Biologia sugerem que se trabalhe o conteúdo da Genética, desenvolvendo competências para a sua compreensão. Para que o professor de Biologia do ensino médio consiga desenvolver essas competências é necessário que, na sua formação inicial sejam desenvolvidas e trabalhadas essas competências, para que os licenciandos, quando formados, possam não só perceber a importância das leis de Mendel, para a compreensão da Genética, mas também para relacionar as tecnologias ligadas à manipulação genética e a importância do seu produto final, as proteínas, na hereditariedade.

É importante, nesse contexto, que as aulas no Ensino Básico ou Superior possibilitem a compreensão das leis de Mendel e os mecanismos da transmissão dos caracteres hereditários, permitindo ao aluno, inseri-lo em outras disciplinas e 
relacioná-lo a outros conteúdos. Para isso se faz necessária à compreensão dos mecanismos da biologia molecular, envolvendo não só a engenharia genética, mas também a transformação dos organismos, o que gera discussão quanto aos aspectos éticos, morais, políticos e econômicos, formando alunos críticos e reflexivos, como sugerem os PCNEM (BRASIL, 1994). 
Referências

BRASIL. Parâmetros Curriculares Nacionais - PCN. Introdução - Ministério da Educação. Secretaria do Ensino Fundamental. Introdução. (5aa aaséries). Brasília. 1998.

BRASIL. Resolução CEB no 3 de 26 de junho de 1998, CNE/98.

BRASIL. Parâmetros Curriculares Nacionais Ensino Médio: PCNEM. Ciências da Natureza, Matemática e suas tecnologia - PCNEM. Brasília: Ministério da Educação, Secretaria de Educação Média e Tecnológica, 1999. 364p.

COSTA, M. V. (Org.) Estudos Culturais em Educação: mídia, arquitetura, brinquedo, biologia, literatura, cinema. Porto Alegre: Editora da Universidade, UFRGS, 2000.

CANAL, R. R.; BASTOS, F. A Abordagem de Temas Contemporâneos no Ensino de Biologia: análise de uma experiência. Encontro Regional de Ensino de Biologia (1:2001: Niterói) Niterói 2001. 504p.

DREYER, D. Educação Brasileira em Penúltimo Lugar -2003-UNESCO (http://www.1.folha.uol.com.br/folha/educacao/20030704-avaliacaointernacional.shtml) acessado em 30/03/2005.

GRIFFITHIS, A. J. F.; MILLER e SUZUKI. Introdução à Genética, 7 ed. Rio de Janeiro: Guanabara-Koogan, 2002. 794p.

MERCADANTE, C. \& FAVARETTO, J. A. Biologia. São Paulo: Moderna, 1999.

MOREIRA, M. C. A.; SILVA, E. P. Concepções Prévias: uma revisão de alguns resultados sobre Genética e Evolução. Encontro Regional de Ensino de Biologia (1:2001: Niterói) Niterói, 2001. 504p. 
MOTTA, P. A. Genética Humana Aplicada à Psicologia e toda a Área Biomédica. Rio de Janeiro: Ed. Guanabara Koogan, 2000.

PERRENOUD, P. Formando Professores Profissionais: quais estratégias? Quais competências? 2 ed. Porto Alegre, RS: Artmed Editora, 2001.

RISCHBIETER, L. Educação Brasileira em Penúltimo Lugar -2003-UNESCO (http://www.1.folha.uol.com.br/folha/educacao/20030701-avaliacaointernacional.shtml) acessado em 30/03/2005.

SCHNETZLER, R. P. O Professor de Ciências: problemas e tendências de sua formação. In: SCHNETZLER, R. P.; Aragão, M. R. (Org) Ensino de Ciências: fundamentos e abordagens. Campinas: CAPES: UNIMEP, 2000. 182p.

TAVARES, M. C. DNA x Transgênicos: um estudo das concepções de licenciandos em biologia. 2004. 80f. Dissertação (Mestrado em Ensino das Ciências) Universidade Federal Rural de Pernambuco, Recife, 2004.

XAVIER, I.; RODRIGUES, S. A.; CAVALCANTI, S. C. H.; MATOS, E. L. Transgênicos. Rio de Janeiro: Âmbito Cultural, 2002. 201p.

Data de recebimento:29/12/2005

Data de aprovação:17/04/2006 